\title{
PENERAPAN KONSELING RATIONAL EMOTIVE BEHAVIORAL DALAM MENGURANGI TINGKAT IRRATIONAL BELIEF KAUM LESBIAN
}

\author{
Silvianetri \\ Program Pascasarjana IAIN Batusangkar \\ Korespondensi: Jl Sudirman No. 137 Kuburajo, Limakaum, Batusangkar, Sumatera Barat, Indonesia \\ email; silvianetri.71@gmail.com
}

\begin{abstract}
Most lesbians are irrational belief in the opposite sex. They consider men to be untrustworthy and evil people. This can be obtained from a bad experience in the family, in which the father is less pleasant towards the mother and from a hostile environment. This condition fosters irrational belief of lesbians towards men. Based on these facts, this study aims to reveal how the application of rational emotive behavioral counseling in reducing the level of irrational belief of lesbians. The research method used is action research. The treatment consists of two cycles, in which one cycle consists of four stages, namely (1) planning, (2) implementation, (3) observation, (4) reflection. Especially at the implementation stage of the counseling steps used are; (a). Accessing the client's self talk, (b). Determining the client's underlying belief, (c) Agreeing on more rational belief, (d) Performing rational emotive imagery, (e). Assigning homework, (f) Positive consequence, and $(g)$ Negative consequence. Respondents in this study amounted to 3 people who indicated lesbians. Respondents were taken based on descriptive random sampling. The results of the analysis of research data revealed that rational emotive behavioral counseling can reduce the level of irrational belief of lesbians. Based on these empirical data it can be concluded that counselors can use rational emotive behavioral counseling in reducing the level of irrational belief of lesbians, so that it is expected to reduce lesbian behavior in society.
\end{abstract}

Keywords: konseling rational emotive behavioral, irrational belief, lesbian

\section{PENDAHULUAN}

$P$ aradigma era modernisasi telah merubah pola pikir dan tingkah laku manusia dari norma-norma agama yang berlaku. Salah satu isu yang santer di bahas akhir-akhir ini adalah keberadaan LGBT (Lesbian, Gay, Biseksual dan Transeksual). Sebagian masyarakat menganggap LGBT tersebut adalah hal yang biasa. Survey nasional (Surnas) SMRC mengungkapkan hasil penelitiannnya bahwa 57,7 persen publik berpendapat bahwa LGBT punya hak hidup di negara kita (walaupun hal tersebut bertentangan dengan agama).
Adapun yang berpendapat sebaliknya hanya sebesar 41,1 persen. Sebagian besar masyarakat menyebut kelompok lesbian, gay, biseksual dan transgender (LGBT) merupakan warga biasa yang memiliki hak yang sama untuk hidup dan tinggal di Indonesia. Setengah dari penduduk Indonesia juga mendorong pemerintah melindungi komunitas tersebut (BBC News Indonesia, 25 Januari 2018).

Selain di kalangan masyarakat, di DPR sebagai lembaga legislatif juga terjadi pro dan kontra tentang keberadaan LGBT di Indonesia. Ketua MPR dan 
Ketua Umum PAN Zulkifli Hasan menyatakan bahwa ada lima partai yang mendukung LGBT dan pernikahan sesama jenis. Pembahasan tentang pro dan kontra LGBT di DPR ini juga banyak disentil di media sosial, yang kemudian jadi perdebatan di kalangan warganet (BBC News Indonesia, 22 Januari 2018).

Setiap tahun angka LGBT di Indonesia semakin menanjak. Banyak media mengekspos jumlah LGBT di Indonesia. Sindo News. Com (23 Mei 2017) menyatakan bahwa jumlah penganut homoseksual termasuk LGBT di Indonesia dari waktu ke waktu semakin meningkat, diperkirakan lebih 3 $\%$ dari jumlah penduduk Indonesia. Peningkatan itu terjadi karena mereka lebih membuka diri atau coming out (mengaku).

Khusus pelajar, yang relatif dalam usia remaja juga termasuk kalangan yang mesti diwaspadai terkait dengan penyuka sesama jenis. Jumlah remaja penyuka sesama jenis memiliki angka yang fantastis, yaitu berkisar 3000 orang. Usman (Arahman.com, 23 Desember 2017) menyatakan bahwa ada 3.000 pelajar di Batam yang menyukai sesama jenis. Pertanyaannya, mungkinkah mereka serentak mengidap kelainan gen?

Tumbuh suburnya LGBT di Indonesia di dukung oleh berbagai faktor, di antaranya dukungan moril dan materil dari berbagai organisasi dan pihak asing. Usman (Arahman.com, 23 Desember 2017) mengungkapkan bahwa penyebaran LGBT didukung oleh dana Internasional yang bertujuan untuk melegalkan LGBT dan perkawinan sejenis. Keberadaan LGBT juga di dukung oleh dua organisasi besar yang aktif melancarkan gerakan advokasi. Organisasi tersebut adalah Gaya Warna Lentera Indonesia (GWL-INA) yang bermitra dengan 119 organisasi yang terkait gay yang ada di 28 provinsi. Organisasi yang kedua adalah LGBTIQ Indonesia, organisasi dan gerakan internasional untuk perilaku seksual yang aneh-aneh.

Salah satu jenis LGBT yang juga sering dibahas publik adalah lesbian. Pada tulisan ini khusus akan membahas lesbian dengan berbagai permasalahannya, serta solusi yang dilakukan untuk mengurangi tingkat lesbian tersebut. Secara etimologi kata lesbian berasal dari kata lesbos, adalah nama sebuah pulau tempat tinggal penyair kuno berkebangsaan Yunani yang bernama Sappho. Pulau Lesbos terletak di sebelah timur Aegean Sea. Pada abad ke 6 SM Sappho mendirikan sekolah khusus perempuan di Pulau Lesbos. Di sekolah tersebut Sappho sering menulis puisi yang menggambarkan gairah kepada muridnya, yang mana sesama perempuan. Kelainan orientasi seksual ini sudah terjadi juga pada zaman nabi Luth, sehingga Allah murka dan memberi azab terhadap mereka yang LGBT ini.

Perempuan lesbian terdiri dari tiga jenis jika ditinjau dari penampilannnya, yaitu; jenis yang perama disebut buchi, yang mana jenis ini perempuan lesbi yang berpenampilan seperti laki-laki, baik rambut maupun pakaiannya. Jenis yang kedua yaitu andro, yang mana andro ini perempuan lesbi mempunyai rambut panjang, tapi berpenampilan dan berpakain seperti laki-laki. Terakhir, yang ketiga yaitu femme, perempuan lesbi yang berpenampilan sama seperti perempuan lainnya. Kaum lesbi ini membentuk komunitas dan kelompok tertentu untuk saling mendukung.

Gaya Nusantara (Sari, tt) mengungkapkan bahwa Sejarah pergerakan lesbian di Indonesia ternyata dimulainya sudah lumayan lama, yaitu sejak berdirinya Perlesin (Persatuan Lesbian Indonesia) di tahun 1982. Kemudian ada Suara Srikandi yang berjuang dengan berkolaborasi dengan organisasi LGBT terbesar Indonesia saat ini yaitu GAYaNusantara. Setelah sempat 
tak terdengar kabarnya beberapa waktu, di tahun 2007 berdirilah Ardhanary Institute yang diprakarsai oleh Saskia Wieringa dan Rr. Agustine. Mungkin Ardhanary Institutelah yang saat ini memiliki resource dan refference terlengkap terkait issue lesbian di Indonesia. Di Surabaya, terdapat banyak kelompok lesbian. Data yang ada di KSGK menunjukkan bahwa sedikitnya terdapat 185 lesbian di surabaya yang tergabung dalam 14 kelompok-3

kelompok kecil beranggotakan 10-20 orang dalam berkomunikasi dan bersosialisasi kebanyakan melalui media sosial, karena mereka lebih leluasa dan terbuka tanpa diketahui khalayak umum. Tirto. id (2018) mengungkapkan bahwa aplikasi kencan khusus yang menawarkan identitas gender sudah ada pada tahun 2012, seiring berkembangnya platform sistem operasi pada android. Sebelum aplikasi berbasis Android meledak, biasanya komunitas homoseksual masih berselancar di situs-situs maya. Khusus lesbian, ada situs kencan Brenda dan Pink Sofa yang menjadi legenda. Seiring kemajuan teknologi, situs-situs kencan homoseksual itu beralih ke aplikasi. Untuk lesbian ada Wapa, Only Women, Her dan Wapa.

Untuk komunikasi lisan mereka menggunakan bahasa khusus yang tidak dimengerti oleh orang di luar kaum lesbian (oudsider). Sari (tt) mengungkapkan dalam hasil penelitinnya bahwa dalam berkomunikasi para lesbian ini menggunakan bahasa dengan simbol tertentu. Contoh bahasa-bahasa tersebut adalah L ,belok ,line, beb ,pem ,GF, lurus, no label, double, linak, american style, pecongan. L , line dan Belok yang merupakan persamaan lesbi, beb adalah Butchi atau yang berperan sebagai lakilaki dalam hubungan lesbi. pem merupakan Femme atau yang berperan sebagai perempuan dalam hubungan lesbi, GF merupakan pasangan/pacar lesbi, lurus merupakan wanita heteroseksual, no label lesbi yang tidak masuk dalam kategori, double adalah dua pasangan lesbi yang sedang berpacaran, linak merupakan laki-laki heteroseksual, pecongan merupakan pasangan lesbi yang sedang berpacaran.

Lesbi ini disebabkan oleh berbagai faktor. Di antara faktor tersebut adalah pengalaman yang menyakitkan dalam keluarga. Budiarty (2011) mengungkapkan bahwa salah satu faktor penyebab timbulnya cinta lesbi, antara lain adanya pengalaman yang cukup menyakitkan dan mendapat perlakuan yang tidak manusiawi dari seorang. Pendapat tersebut juga di dukung dengan hasil wawancara penulis pada tanggal 3 April 2018 dengan salah seorang lesbi (dengan inisial $\mathrm{Y}$ ), $\mathrm{Y}$ mengungkapkan bahwa dia merasa benci dan marah pada ayahnya ketika ketahuan berselingkuh dengan wanita lain. Padahal ibu Y tidak mempunyai kesalahan dan kekurangan apapun. Sejak itu Y mempunyai keyakinan bahwa laki-laki adalah makhluk egois dan jahat, sehingga $\mathrm{Y}$ tidak punya ketertarikan terhadap lakilaki. Dia lebih senang dan tertarik pada perempuan. Begitu juga wawancara penulis dengan salah seorang lesbi yang tinggal di kota X, yang berinisial B. B mengaku lesbi disebabkan sering melihat bapaknya melakukan kekerasan pada ibunya, sehingga dia kabur dari rumah. Sejak itu dia tinggal di kolong jembatan dan lebih senang bergaul dengan wanita. $\mathrm{X}$ merasa nyaman walaupun jauh dari orang tua. Akhirnya dia jatuh cinta dengan teman wanitanya.

Faktor selanjutnya yang menyebabkan seorang lesbian adalah faktor lingkungan. Budiarty (2011) mengungkapkan bahwa faktor ekologi atau lingkungan memiliki peranan penting mengapa terjadinya homoseksualitas wanita atau yang disebut dengan lesbian. Ternyata pada umumnya mereka tidak mengetahui mengapa 
mereka memilih untuk menjadi seorang lesbian. Jadi dapat dikatakan keadaan yang terjadi pada lesbian tersebut bukan atas keinginan sendiri. Terkadang karena pengaruh teman atau gaya hidup.

Lesbian yang disebabkan oleh faktor keluarga atau lingkungan cenderung berpikir irrasional terhadap laki-laki. Artinya kaum lesbian menganggap lakilaki adalah orang yang tidak baik dan tidak pantas untuk dicintai. Hal ini dikarenakan mereka kerap mengalami perlakuan yang tidak menyenangkan dari laki-laki, atau dalam pandangan kaum lesbian wanita lebih perhatian dan penuh kasih sayang di banding laki-laki. Jika irrational belief ini tetap dipertahankan maka dis-orientasi seksual kaum lesbian akan sulit untuk dihilangkan.

Untuk menghilangkan irrational belief kaum lesbian ini, salah satunya memakai pendekatan konseling yaitu Konseling Rational Emotive Behavioral (KREB). Langkah-langkah konseling yang digunakan yaitu; Langkah langkah konseling yang yang digunakan yaitu; (a). Accesing the client'self talk, (b). Determining the client's underlying belief, (c) Agreeing on more rational belief, (d) Performing rational emotive imagery, (e). Assigning homework, (f) Positive consequence, dan ( $g$ ) Negative consequence. Berdasarkan berpakai fakta dan dukungan oleh teori di atas, maka penulis merasa penting untuk menungkapkan penerapan konseling rational emotive behavioral dalam menurunkan tingkat irrational belief kaum lesbian.

\section{Irrational Belief dan Konseling REB Pada Lesbian}

Konseling Rational Emotive Behavior dipelopori oleh Albert Ellis. Pakar konseling Erford (2017:269) mengungkapkan bahwa Rational Emotif Behavior Therapy diciptakan oleh Albert Ellis pada tahun 1955. Selanjutnya dituliskan bahwa dalam REBT emosi adalah hal yang penting, akan tetapi kognisi seseorang adalah sumber dari berbagai masalah psikologis. Ide dasar teorinya adalah mengubah keyakinan irasional menjadi keyakinan yang fleksibel dan rasional.

Konsep utama dari Konseling Rational Emotive Behavior adalah Model ABCD. Corey (2005) mengungkapkan bahwa teori A-B-C adalah teori sentral yang sangat mempengaruhi teori dan praktik REBT. A adalah situasi atau peristiwa yang mengaktifkan keyakinan seseorang. Pada penelitian ini A adalah sikap laki-laki yang kurang bersahabat terhadap perempuan. Situasi atau peristiwa tersebut terkait dengan masa lalu, masa sekarang dan bayangan masa yang akan datang. B, adalah keyakinan seseorang terhadap suatu peristiwa atau situasi. Keyakinan ini dibagi atas dua jenis, rasional atau tidak rasional (irasional). C adalah konsekuensi emosi dan perilaku seseorang akibat keyakinan terhadap suatu peristiwa atau situasi. Jadi, dapat disimpulkan bahwa emosi dan perilaku sangat terkandung pada keyakinan seseorang.

Perbedaan orang yang mempunyai keyakinan rasional dan irasional akan terlihat dari pola pikir dan perilakunya. Dryden dan Mytton (1999) mengungkapkan perbedaan keyakinan rasional dan keyakinan irasional, seperti yang di uraikan pada Tabel 1 berikut.

Tabel 1. Karakteristik Rasional Belief dan Irasional Belief

\begin{tabular}{|l|l|l|}
\hline No & Rational Belief & \multicolumn{1}{|c|}{ Irrational Belief } \\
\hline 1. & $\begin{array}{l}\text { Fleksibel dan } \\
\text { bijaksana, dengan } \\
\text { mengungkapkan } \\
\text { kata saya "ingin", } \\
\text { "suka", "mau". }\end{array}$ & $\begin{array}{l}\text { Kaku } \\
\text { dogmatis, sering } \\
\text { menggunakan } \\
\text { kata "harus" }\end{array}$ \\
\hline 2. & $\begin{array}{l}\text { Konsisten dengan } \\
\text { kenyataan }\end{array}$ & $\begin{array}{l}\text { Tidak konsisten } \\
\text { dengan kenyataan }\end{array}$ \\
\hline 3. & Berpikir logis & $\begin{array}{l}\text { Berpikir tidak } \\
\text { logis }\end{array}$ \\
\hline 4. & Pragmatis dalam & Tidak pragmatis \\
\hline
\end{tabular}




\begin{tabular}{|l|l|l|}
\hline & bertindak & dalam bertindak \\
\hline
\end{tabular}

Sumber : Dryden and Mytton (1999)

Pada Tabel 1 terlihat bahwa orang yang mempunyai keyakinan rasional lebih fleksibel, konsisten dengan kenyaataan, logis dan pragmatis di banding orang yang irasional belief. Jika dilihat dari cara pandang kaum lesbian, sebagian besar mereka bersikap irasional belief terhadap laki-laki. Mereka berpandangan bahwa laki-laki adalah kaum yang tidak pantas untuk dijadikan pasangan hidup. Perempuan adalah pasangan yang pantas untuk disayangi dan dicintai, sekaligus dijadikan pasangan hidup. Keyakinan tersebut kaku dan tidak rasional. Seandainya orang membangun rumah tangga dengan pasangan sejenis, tentu saja tidak akan ada generasi penerus (anak) . Kondisi ini akan membuat populasi manusia di bumi semakin berkurang. Cara pandang irrasional lesbian ini akan membawa mereka pada perilaku yang tidak pragmatis.

Untuk menurunkan tingkat irrasional belief ada beberapa langkah yang dapat digunakan Pada Konseling Rational Emotive Behavior. Erford et al,. (2010) menguraikan langkah-langkah Konseling Rational Emotif Behavior, yaitu; (a). Accesing the client'self talk, (b). Determining the client's underlying belief, (c) Agreeing on more rational belief, (d) Performing rational emotive imagery, (e). Assigning homework, (f) Positive consequence, dan ( $g$ ) Negative consequence

Corey (2005) mengungkapkan bahwa rational emotive imagery adalah sebuah teknik yang dirancang untuk membuat pola emosi yang baru, yang mana klien diminta untuk membayangkan fikiran, perasaan dan tingkah laku yang diinginkan dan mempraktikkannya dalam kenyataan.

Berdasarkan pendapat di atas dapat dimaknai bahwa berbagai teknik dalam konseling Rational Emotive Behavior di duga dapat dijadikan treatment untuk mengurangi tingkat ingkat irasional belief terhadap kaum lesbian. Penerapan konseling Rational Emotive Behavior sangat ditentukan oleh wawasan, keterampilan dan keprofesionalan konselor.

\section{Metodologi Penelitian}

Penelitian ini menggunakan jenis penelitian kualitatif, khususnya action research. Ferriance (2000:2) mengungkapkan bahwa action research adalah suatu penelitian yang dimulai dari masalah, yang mana masalah tersebut harus dicarikan solusinya. Penelitian yang akan dilakukan terdiri dari dua siklus tindakan. Metode penelitian tindakan dirancang berdasarkan apa yang dikemukakan oleh Arikunto (2011 : 236) yaitu ada empat tahapan penelitian dalam satu siklus. Adapun uraian dalam satu siklus tersebut adalah ; (1) perencanaan, (2) Pelaksanaan, (3) Pengamatan, (4) Refleksi. Apabila kegiatan siklus pertama sudah diketahui letak keberhasilan dan hambatannya, maka peneliti menentukan rancangan untuk siklus kedua berdasarkan refleksi siklus pertama hingga mencapai hasil yang diharapkan. Adapun rancangan penelitian tergambar pada Diagram 1. 
Diagram 1. Rancangan Penelitian Action Research
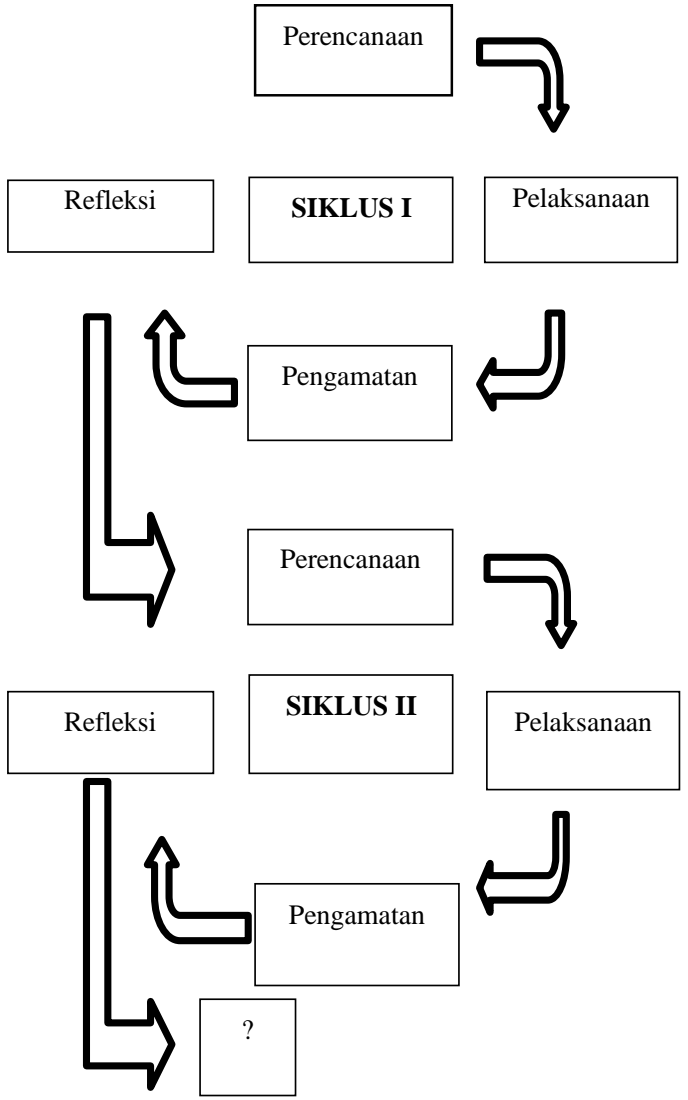

Rancangan penelitian di atas menggambarkan bahwa ada empat tahap yang harus dilalui dalam action research. Ketika ditemukan suatu masalah, maka dibuatlah perencanaan penelitian, selanjutnya dilaksanakan penelitian, setelah itu dilakukan pengamatan. Terakhir dilakukan refleksi terhadap hasil pengamatan. Responden dalam penelitian ini berjumlah 3 orang yang terindikasi lesbian. Responden diambil berdasarkan porpusive random sampling. Untuk pengambilan data penelitian menggunakan Skala Irrational Belief, yang berjumlah 24 item. Adapun kisi-kisi skala terlihat pada Tabel 2 .
Tabel 2. Kisi-kisi Skala Irrational Belief Kaum Lesbian

\begin{tabular}{|c|c|c|c|}
\hline $\begin{array}{c}\mathrm{N} \\
\mathrm{o}\end{array}$ & Sub Variabel & Favorabel & $\begin{array}{c}\text { Unfavora } \\
\text { bel }\end{array}$ \\
\hline 1. & $\begin{array}{c}\text { Kaku (Tidak } \\
\text { fleksibel) }\end{array}$ & $1,2,3$ & $4,5,6$ \\
\hline 2. & $\begin{array}{c}\text { Tidak } \\
\text { konsisten } \\
\text { dengan } \\
\text { kenyataan }\end{array}$ & $7,8,9$ & $10,11,12$ \\
\hline 3. & $\begin{array}{c}\text { Berpikir } \\
\text { tidak logis }\end{array}$ & $13,14,15$ & $16,17,18$ \\
\hline 4. & $\begin{array}{c}\text { Tidak } \\
\text { pragmatis }\end{array}$ & $19,20,21$ & $22,23,24$ \\
\hline
\end{tabular}

Responden Lesbian yang akan diberikan treatment diukur terlebih dahulu tingkat irasional beliefnya dengan Skala Irrational Belief (SIB). Skala Irrational Belief berjumlah item 24 butir. 24 Butir pernyataan yang terkait dengan irasional belief dan 24 pernyataan terkait dengan rasional belief. Untuk kategori terkait dengan karakteristik irasional belief lesbian digunakan norma seperti Tabel 3 di bawah.

Tabel 3. Deskripsi Karakteristik Tingkat Irrational Belief

\begin{tabular}{|c|c|c|}
\hline No & $\begin{array}{c}\text { Rentang } \\
\text { Skor }\end{array}$ & $\begin{array}{c}\text { Karakteristik } \\
\text { Tingkat Irrational } \\
\text { Belief }\end{array}$ \\
\hline 1 & $65-96$ & Tinggi \\
\hline 2 & $33-64$ & Sedang \\
\hline 3 & $0-32$ & Rendah \\
\hline
\end{tabular}

Wanita lesbi yang tinggi irasional beliefnya akan diberikan treatment yang ada dalam Konseling Rational Emotive Behavior. Adapun lesbi dengan kategori tingkat irasional beliefnya tinggi memiliki skor 65-96. Tingkat irasional belief sedang mempunyai skor 33-64, dan irasional belief yang rendah skornya berkisar antara 0-32. 


\section{HASIL PENELITIAN}

Responden penelitian berjumlah 3 orang dengan inisial $\mathrm{Y}, \mathrm{X}$ dan T. Mereka berasal dari latar belakang yang berbedabeda, dan penyebab lesbiannya berbeda juga. Adapun deskripsi tentang responden akan diuraikan seperti di bawah ini.

$\mathrm{Y}$ adalah seorang perempuan yang berpenampilan seperti laki-laki jika di luar rumah dan di luar kampus. Berbeda ketika y berada di rumah, Y tetap memakai jilbab karena takut ketahuan sama orang tuanya. Rambut $\mathrm{Y}$ pendek seperti laki-laki. Kalau dilihat penampilan $\mathrm{Y}$ dia tergolong lesbian buchi. Umur Y 22 tahun. Y merupakan anak angkat dari keluarga pengusaha yang kaya raya. Y lesbi semenjak kelas 1 SMA, dikarenakan dia kecewa dengan sikap ayah angkatnya yang telah berselingkuh dengan wanita lain. Semenjak itu Y senang dan tertarik dengan perempuan. Y Sering mentraktir teman-teman perempuannya, begitu juga dengan pacarnya yang berjenis kelamin perempuan.

Lesbi selanjutnya berinisial X, Umur 25 tahun. $X$ berasal dari keluarga yang sederhana. Ayah dan Ibu $X$ sering bertengkar, dan tak jarang ibunya mendapat perlakuan kasar dari ayahnya. Ibunya sering di tempeleng dan di tendang. $\mathrm{X}$ tidak tahan menghadapi situasi tersebut, dia kabur dari rumah dan menjadi anak gelandangan. Ketika itu X berumur 16 tahun. Di jalanan $X$ mendapat perhatian dari teman temannya sesama perempuan. Di antara teman tersebut ada yang lesbi, akhirnya $\mathrm{X}$ berpacaran dengan teman yang lesbi tersebut. X menjalani hidup yang kelam, tanpa ada yang mengarahkan. Untuk kehidupan sehari-hari $\mathrm{X}$ mengamen bersama teman-temannya.

Lesbi yang ketiga adalah $\mathrm{T}, \mathrm{T}$ mengaku lesbi karena dia tinggal di asrama yang semuanya perempuan. Ketika tingkat SMP $\mathrm{T}$ mulai tertarik dengan kakak tingkatnya yang aktif di organisasi kuliah. Menurut pengakuan T, banyak teman-temannya yang berpacaran dengan kakak tingkat. Malah banyak kakak tingkat tersebut hanya memanfaatkan adik tingkatnya untuk kepentingan pribadi.

Lesbian yang akan diberikan treatment diukur terlebih dahulu tingkat irasional beliefnya dengan Skala Irrational Belief (SIB). Ada tiga tingkatan irasional belief, yaitu tinggi, sedang dan rendah. Gambaran tentang tingkatan irasional belief tersebut ada pada Tabel 4 di bawah.

Tabel 4. Deskripsi Tingkat Irasional Belief Sebelum diberi Treatment

\begin{tabular}{|c|c|c|c|}
\hline No & Inisial & Skor & Kategori \\
\hline 1. & $\mathrm{Y}$ & 72 & Tinggi \\
\hline 2. & $\mathrm{X}$ & 80 & Tinggi \\
\hline 3. & $\mathrm{~T}$ & 78 & Tinggi \\
\hline
\end{tabular}

Pada Tabel 4 di atas terlihat bahwa $\mathrm{Y}, \mathrm{X}$ dan $\mathrm{T}$ mempunyai tingkat irasional belief yang tinggi, yaitu skor mereka berada pada rentang 65-96. Untuk menurunkan tingkat irasional, perlu diberikan treatment. Pada penelitian ini treatmen diberikan dalam 3 siklus. Setelah diberikan treatmen terjadi penurunan tingkat irasional belief responden. Uraian lengkapnya ada pada Tabel 5 di bawah.

Tabel 5. Deskripsi Tingkat Irasional Belief Setelah diberi Treatment

\begin{tabular}{|c|c|c|c|c|c|c|c|}
\hline $\mathrm{N}$ & Ini & & Skol & & & ateg & \\
\hline & & & & & & & \\
\hline & & $\mathrm{Si}$ & $\mathrm{Si}$ & $\mathrm{Si}$ & Sik & Sik & Sik \\
\hline & & kl & $\mathrm{kl}$ & $\mathrm{kl}$ & lus & lus & lus \\
\hline & & us & us & us & 1 & 2 & 3 \\
\hline & & 1 & 2 & 3 & & & \\
\hline 1 & $Y$ & 65 & 57 & 54 & Tin & $\mathrm{Se}$ & Sed \\
\hline & & & & & ggi & dan & ang \\
\hline & & & & & & $\mathrm{g}$ & \\
\hline
\end{tabular}




\begin{tabular}{|c|c|c|c|c|c|c|c|}
\hline $\begin{array}{c}2 \\
\cdot\end{array}$ & $\mathrm{X}$ & 61 & 49 & 26 & $\begin{array}{c}\mathrm{Se} \\
\text { dan } \\
\mathrm{g}\end{array}$ & $\begin{array}{c}\mathrm{Se} \\
\text { dan } \\
\mathrm{g}\end{array}$ & $\begin{array}{c}\mathrm{Re} \\
\mathrm{nda} \\
\mathrm{h}\end{array}$ \\
\hline 3 & $\mathrm{~T}$ & 60 & 53 & 30 & $\begin{array}{c}\mathrm{Se} \\
\text { dan } \\
\mathrm{g}\end{array}$ & $\begin{array}{c}\mathrm{Se} \\
\text { dan } \\
\mathrm{g}\end{array}$ & $\begin{array}{c}\mathrm{Re} \\
\text { nda } \\
\mathrm{h}\end{array}$ \\
\hline
\end{tabular}

Pada Tabel 5 di atas terlihat bahwa $\mathrm{Y}, \mathrm{X}$ dan $\mathrm{T}$ mengalami tingkat penurunan irasional belief setelah diberikan treatment, yang mana skor $\mathrm{Y}$ sebelum diberi treatment adalah 72, dan setelah diberi treatmen 3 siklus turun menjadi 54 . Begitu juga dengan $X$, telah terjadi penurunan tingkat irasional beliefnya setelah diberikan treatment dengan 3 siklus, yaitu dari skor 80 menjadi skor 26. Pada responden $\mathrm{T}$ juga terjadi penurunan irasional beliefnya, yaitu dari skor 78 , menjadi skor 30 . Berdasarkan data empiris tersebut dapat disimpulkan bahwa ketiga responden telah mengalami penurunan tingkat irasional beliefnya setelah diberikan konseling Rational Emotive Behavior.

\section{PEMBAHASAN}

Berpikir irasional akan menjadikan seseorang berpikir tidak logis yang nantinya tercermin dalam sikap dan tingkah laku. Begitu juga dengan kaum lesbian, mereka mencari pasangan dengan sesama jenis, bukan dengan lawan jenis. Allah dalam Alquran memerintahkan manusia untuk mencari pasangan dengan lawan jenis, seperti dalam Ayat Alquran berikut:

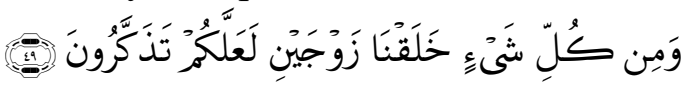

Artinya: Dan segala sesuatu kami ciptakan berpasang-pasangan supaya kamu mengingat kebesaran Allah. (QS. AdzDzaariyat: 49)

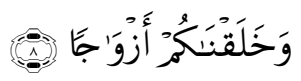

Artinya: Dan kami jadikan kamu berpasang-pasangan (Q.S. AnNaba': 8).

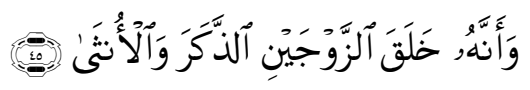

Artinya: Dan bahwasanya dialah yang menciptakan berpasang-pasangan pria dan wanita (QS. An-Najm: 45)

Ayat di atas menjelaskan bahwa fitrah manusia di ciptakan Allah adalah berpasang pasangan antara laki-laki dengan perempuan. Selanjutnya Allah menegaskan pada fitrah tersebut bahwa setiap pasangan dapat mengingat kebesaran Allah. Artinya pada penciptaan manusia secara berpasangan akan mendorong manusia mengenal kebesaran Allah. Selanjutnya ditegaskan Allah dalam firmanNya sebagai berikut.

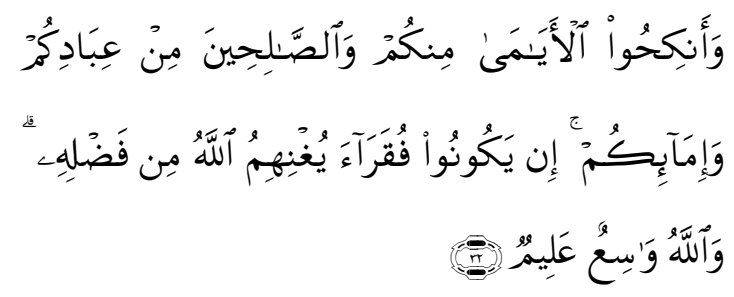

Artinya: Dan kawinkanlah orang-orang yang sedirian diantara kamu, dan orang-orang yang layak (berkawin) dari hamba-hamba sahayamu yang lelaki dan hamba-hamba sahayamu yang perempuan. jika mereka miskin Allah akan memampukan mereka dengan kurnia-Nya. dan Allah Maha luas (pemberian-Nya) lagi Maha Mengetahui (QS An Nur:32).

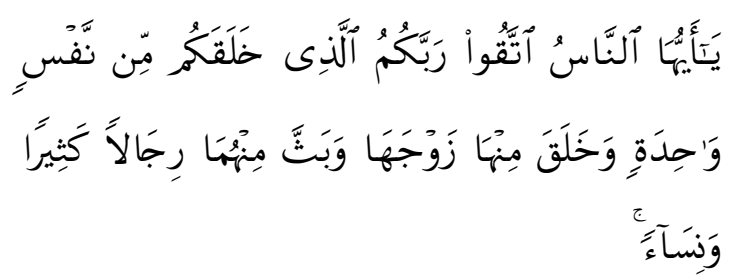




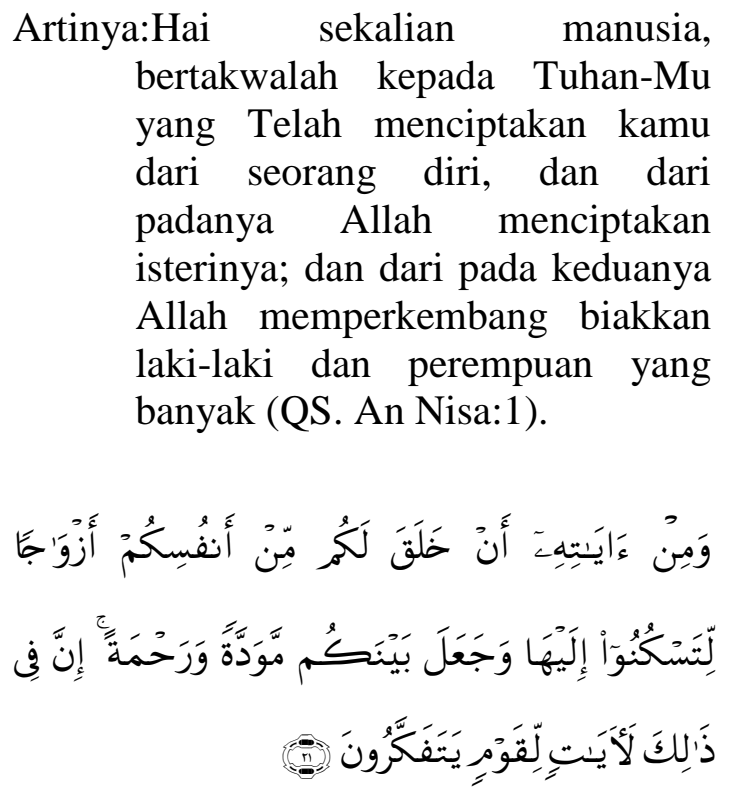

Artinya: dan di antara tanda-tanda kekuasaan-Nya ialah dia menciptakan untukmu isteri-isteri dari jenismu sendiri, supaya kamu cenderung dan merasa tenteram kepadanya, dan dijadikan-Nya diantaramu rasa kasih dan sayang. Sesungguhnya pada yang demikian itu benar-benar terdapat tanda-tanda bagi kaum yang berfikir (QS. Ar Rum:21)

Pada Ayat Alquran di atas sudah dijelaskan bahwa dengan mengenal lawan jenis, serta membentuk rumah tangga adalah dalam rangka menentramkan jiwa manusia itu sendiri. Menikah dengan lawan jenis diharapkan akan mempunyai keturunan untuk jadi generasi penerus. Kalau lesbian dibiarkan tentu populasinya semakin banyak, hal ini akan mengancam kelangsungan generasi manusia di bumi.

Berdasarkan data empiris di atas, Konseling Rational Emotive Behavior dapat menurunkan tingkat irasional belief kaum lesbian, yang nanti diharapkan juga dapat mengurangi jumlah lesbian yang ada di Indonesia.

\section{PENUTUP}

Fitrah manusia adalah mencintai lawan jenis. Para lesbian telah mengingkari fitrahnya sebagai manusia, karena lebih cinta dan tertarik dengan sesama jenis. Ketertarikan dengan sesama jenis disebabkan karena pemikiran yang irasional. Untuk menghilangkan lesbian, langkah utama yang mesti dilakukan adalah menurunkan tingkat irasional belief. Salah satu cara yang dapat dilakukan adalah melalui Koneling Rational Emotive Behavior. Secara empiris konseling Rational Emotive Behavior telah membuktikan bahwa konseling ini telah dapat menurunkan tingkat irasional belief kaum lesbian. Berdasarkan fakta tersebut, alangkah baiknya para praktisi konseling untuk menggunakan Konseling Rational Emotive Behavior dalam menurunkan tingkat irasional belief kaum lesbian secara khusus, dan kasus kasus lainnya yang terkait dengan irasional belief.

\section{DAFTAR RUJUKAN}

Al-Qur'an

Arikunto, S. 2011. Prosedur Penelitian; Suatu Pendekatan Praktik, Edisis Revisi VII. Jakarta: Rineka Cipta

BBC News Indonesia. 2018. Mayoritas rakyat Indonesia menerima hak hidup LGBT. Online.

https://www.bbc.com/indonesia/indonesi a-42813753. di update 25 Januari.

BBC News Indonesia. 2018. Politisasi atau kriminalisasi LGBT: dari 'lima partai pendukung' sampai 'kucuran dana asing'. Online. https://www.bbc.com/indonesia/tr ensosial-42771018. Di update 22 Januari.

Budiarty A. 2011. Gaya Hidup Lesbian (Studi Kasus dI Kota Makasar). Makasar: Universitas Hasanuddin Masakasar 
Corey, G. 2005. Theory and Practice of Counseling and Psychotherapy (Seven Edition). New York .: Thomson Brook/Cole

Dryden, W and Mytton, J. 1999. Four Approaches to Counseling and Psychotherapy. New York: Routledge.

Erford, B.T. 2017. 40 Teknik yang Harus diketahui Setiap Konselor (terjemahan). Yokyakarta: Pustaka Pelajar.

Erford, B.T, Eaves, S.H, Bryant E. M, and Young, K.A. 2010. 35 Techniques Every Counselor Should Know. New Jersey : Merill Ferriance, E. 2000. Action Research. New York: Brown University

Nurmala, D, Anam, C, Suyono, H. 2006. Studi Kasus Perempuan Lesbian (Bucthy) di Yogyakarta. Jurnal Humanitas : Indonesian Psychological Journal Vol. 3 No. 1 Januari $2006: 28$ - 37

Sari, I.P. TT. Simbol Interaksi Kaum Lesbi. Surabaya: Universitas Airlangga Surabaya

Sindo News.com. 2017. LGBT Makin Terbuka, Jumlah Penganut Homoseksual di Indonesia Meningkat. Online. https://metro.sindonews.com/read /1207367/ $171 \quad$ /lgbt-makinterbuka-jumlah-penganuthomoseksual-di-indonesiameningkat-1495508852. Update 23 Mei 2017.

Tirto.id. 2018. Gairah Kencan Online Kaum LGBT di Indonesia. Online. https://tirto.id/gairahkencan-online-kaum-lgbt-diindonesia-ctrW. diakses 13 Juli 2018.

Usman, A. 2017. LGBT; Angka-angka, Gerakan, dan Proyeksi ke Depan. Online. Arahman.com, 23 Desember. 